UC-25 and UC-77

1ssued: December 1977

\title{
High-Temperature Fuel Technology for Nuclear Process Heat: \\ ZrC-Containing Coated Particle Fuels and High-Density Graphite Fuel Matrices
}

Paul Wagner

An Alfirmative Action/Equal Opportunity Employer 


\section{HIGH-TEMPERATURE FUEL TECHNOLOGY FOR NUCLEAR PROCESS HEAT: \\ ZrC-CONTAINING COATED PARTICLE FUELS AND HIGH-DENSITY GRAPHITE FUEL MATRICES}

\author{
by \\ Paul Wagner
}

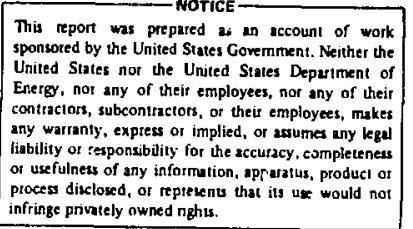

\begin{abstract}
This is the final report on the high-temperature, gas-cooled reactor fuels project that was pursued at the Los Alamos Scientific Lahoratory from eariy 1973 to mid-1977. This work followed two broad paths: (1) ZrC was utilized in various ways to improve the temperature capability of fissionproduct-retaining coated nuclear fuel particles and (2) techniques were developed for fabricating fuel rods by extruding the coated particles in highdensity graphite matrices.

The key to the $\mathrm{ZrC}$ coating project proved to be the $\mathrm{ZrCl}_{4}$ powder feeder development. The $\mathrm{ZrCl}_{4}$ reacted with $\mathrm{H}_{2}$ and $\mathrm{CH}_{6}$ or $\mathrm{C}_{3} \mathrm{H}_{6}$ to produce chemically vapor-deposited (CVD) ZrC. This CVD ZrC was used on nuclear fuel particles for replacing the $\mathrm{SiC}$ in the TRISO-II design, for making $\mathrm{ZrC}$ C graded coats, and for making $\mathbf{Z r C}$-alloyed isotropic carbon coats. Fuel particles with all of the described coats have been very successful in hightemperature, full-fluence $\left(8 \times 10^{21} \mathrm{n}^{\mathrm{cm}^{-2}}\right)$ irradiation tests. Hightemperature diffusion experiments with cesium showed that $\mathrm{ZrC}$ is comparable to SiC as a diffusion barrier.

Extruded fuel rods with matrix densities of 1.6 to $1.7 \mathrm{~g} \mathrm{~cm}^{-9}$ and with up to 45-vol\% coated particles were made without difficulty. All fuel rods tested in high-temperature, full-fluence irradiations had excellent results.
\end{abstract}

\section{INTRODUCTION AND BACKGROUND}

The purpose of this project was to develop improved coated-particle, graphite-matrix nuclear fuels, which could be used in gas-cooled power reactors to obtain the higher coolant outlet temperatures that are required for high-temperature nuclear prorsss heat. We utilized LASL's (Los Alamos Scientific Laboratory) extensive expertise and existing equipment in coated-particle development, graphite research, fabrication of graphite-base fuel bodies, nondestructive testing, and physicalproperty measurements. The program included ( $a$ ) design and development of improved fissionproduct-retaining coated particles to permit increased temperature capability, (b) development of improved fuel rods by extruding commercially available coated particles of contemporary design and improved ZrC-coated particles in high-density graphite, and (c) evaluation of coated particles and 
fuel bodies by neutron-activation, thermal, and prolonged high-temperature irradiation tests.

The work followed two broad paths:

- Chemically vapor-deposited (CVD) ZrC was utilized in various ways to improve the temperature capability of fission-product-retaining coated part:cles. Initially, TRISO-II design coated particles with $\mathrm{UC}$, kernels and with $\mathrm{ZrC}$ coats in place of the $\mathrm{SiC}$ were computer designed and made at LASL. These and other particles with $\mathrm{ZrC}$ coatings were irradiation-tested at the Oak Ridge National Leboratory (ORNL) as quickly as they could be prepared and arrangements made for the irradiations.

- A continuous process fuel-rod fabrication was studied. Initially these studies were made using commercially available high-temperature, gascooled reactor (HTGR) fissile and fertile coated particles. Ultimately LASL-made high-temperature particles were used in the studies. Extrusion methods of fabrication were applied to the development of the coated-particle, graphite-matrix fuel bodies. We studied (a) coated-particle mechanical damage caused by extrusion geometry and volume loading of particles (b) effects of binder, flour, mixing procedures, and use of fugitive solvents for blending and eztruding the fuel bodies, and (c) effects of curing, baking, and final heat-treatment conditions. Full-scale extrusions were made to size and evaluated. High-temperature gas-leaching (in $\mathrm{Cl}_{2} / \mathrm{CO}_{2}$ mixtures) techniques were used for removing exposed heavy metal. These fuel rods were subjected to prolonged high-temperature irradiation tests at ORNL.

Use of the $\mathrm{ZrC}$ in place of the $\mathrm{SiC}$ permits the use of processing temperatures as high as $2475 \mathrm{~K}$ for cuated-particle, graphite-matrix fuel bodies. The product of this heat treatment was a dispersion of coated fuel porticles in a graphite matrix whose thermal conductivity (at $300 \mathrm{~K}$ ) was markedly higher $\left[\lambda \simeq 70-80 \mathrm{~W} \mathrm{~m}^{-2} \mathrm{~K}^{-1}\right.$ (Ref. 1$\left.)\right]$ than that of the fuel sticks in the HTGR $\left(\lambda \simeq 8-10 \mathrm{~W} \mathrm{~m}^{-1} \mathrm{~K}^{-1}\right)$. Such heat-treated fuel rods, if used in an HTGR, would result in higher coolant, temperatures without increasing coated-particle operating temperatures or would allow the reactor to operate with current design coolant temperatures at lower coatedparticle fuel temperatures."

We have met the anticipated programmatic goals, without exception, and have included additional goals that have proved to be germane to very-hightemperature, gas-cooled reactor (VHTR) systems.

\section{THE COATED-PARTICLE PROGICAM}

As an early step in the use of $\mathrm{ZrC}$ for coated particles, the thermal stress pertiorimance of a TRISO-II particle with $\mathrm{ZrC}$ in place of $\mathrm{SiC}$ was computed using the Dragon Project Stress-2 code.* Using a modulus of $0.4 \mathrm{TPa}\left(6 \times 10^{7} \mathrm{psi}\right)$ for the $\mathrm{ZrC}$, we calculated that for HTGR full-term conditions of 0.74 FIMA (Fraction of Initial Metal Atoms) and a total fluence of $8 \times 10^{21} \mathrm{n} \mathrm{cm}^{-2}(\mathrm{E}>0.18 \mathrm{MeV})$, there was a safety margin of a factor of 4 in strength (or thickness).

Another early requirement in the $\mathrm{ZrC}$-coatedparticle program was modification of existing laboratory equipment and fabrication of new equipment. This was required to meet the dual requirements of pursuing a research and development $(R$ and D) program on fluidized-bed $\mathrm{ZrC}$ particlecoating processes and supplying the extrusion facility with a sufficient quantity of particles to pursue the $R$ and $D$ program in fuel-rod extrusion fabrication. The key to the achievement of both goals was the development, fabrication, and operation of the $\mathrm{ZrCl}_{4}$ powder feeder. ${ }^{2}$ Details on the construction and use of the $25-\mathrm{mm}$ powder feeder are in the open literature published under the aegis of this program. 4.8 Fluidized-bed coaters of 25 - and $76-\mathrm{mm}$ diameter were used (details on the 76-mm coater are in Appendix A). The 25-mm coater was of conventional design, induction heating was used, and temperature measurement was by thermocouples. The 76-mm coater was of similar design utilizing a single nozzle (other coaters of this capacity normally use multiple nozzles or turbulence generators). No particular difficulties were encountered in developing these systems.

There are several ways to use $\mathrm{ZrC}$ in particle ca.ts; making discrete $\mathrm{ZrC}$ coats, making $\mathrm{ZrC}-\mathrm{C}$ composite (or alloy) coats, and making ZrC-C graded coats. Our interest in co-depositing $\mathrm{ZrC}$ and low-temperature isotropic pyrolytic carbon (LTI) was stimulatei by the possibility of making coats with improved thermal and irradiation performance

*We gratefully acknowledge ORNL's cooperation in obtaining this code. 
by a simpler fabrication process than that used for the HTGR fissile particles. With a controllable codeposition process, a continuously graded coat can be made that starts out as pure LTI and has ZrC added in evenly increasing amounts (by reaction of $\mathrm{ZrCl}_{4}$ with the hydrocarbon) until pure $\mathrm{ZrC}$ is deposited. The process can then be reversed and the $\mathrm{ZrC}$ decreased to get back to the LTI. The stress, which is generated by a mismatch of the thermal expansion coefficients of two adjoining components, would be minimized in such a coat. Such a process would be a single fabrication step and couid be used as a substitute for the three separate steps used in the outermost layers of the TRISO-type coated particles. Other advantages to a graded coat could be reduction of the radiation-induced creep in the LTI with a subsequent decrease in the creep-induced stresses in the outermost coats (one of the causes of coat failure at high fluence). The reduction of the magnitude of the physical-properties mismatch achieved by the graded coat would be an additional favorable factor. Addition of $\mathrm{ZrC}$ to the LTI eliminates changes in density and Bacon Anisotropy Factor (BAF) in the LTI under high fluence and improves the retention of the solid fission products. The behavior of LASL-made particles having ZrCdoped LTI coats that were irradiated in the ORNL High-Fluence Isotope Reactor (HFIR) HT-31 experiment ${ }^{\circ}$ was excellent. These particles were irradiated at $1525 \mathrm{~K}$ to a nominal fluence of $8 \times 10^{21}$ $n \mathrm{~cm}^{-2}$ ( $\mathrm{E}>0.18 \mathrm{MeV}$ ) with no perceptible changes (macro or micro) as a result of the irradiation. Thus, the potential implied in the use of the $\mathrm{ZrC}$-doped LTI coats is also very great.

These ideas are not necessarily original with LASL. The General Atomic Company, the European Dragon Project, the Austrian group at Seibersdorff, and the Japanese Atomic Energy Research Institute have all tried making ZrC-coated particles. In our discussions with KFA (Kernforshunge Anlage, FR( $r$ ), the Germans indicated strong interest in the $\mathrm{ZrC}$ coats, but in view of the fabrication problems described they have chosen to concentrate on other materials.

The $\mathrm{ZrC}$ is made by the reaction of a hydrocarbon gas with a airconium halide-usually $\mathrm{ZrCl}_{\text {. }}$. Quantitative control of the vaporization of the $\mathrm{ZrCl}$ has been the chief obstacle to the successful co- deposition process in the past. LASL solved this problem by using the described $\mathrm{ZrCl}_{4}$ powder feeder. This method has proved to be controllable and reproducible. Quantitative experiments on preparation of substoichiometric: $\mathrm{ZrC}$ using the reactions

$\mathrm{ZrCl}_{4}+\mathrm{xCH}_{4}+2(1-x) \mathrm{H}_{2}=\mathrm{ZrC}_{\mathrm{x}}+4 \mathrm{HCl}$

and

$3 \mathrm{ZrCl}_{6}+\mathrm{xC}_{2} \mathrm{H}_{8}+3(2-\mathrm{x}) \mathrm{H}_{2}=3 \mathrm{ZrC}_{\mathbf{x}}+12 \mathrm{HCl}$

have been carefully performed and documented. ${ }^{7-0}$ LTI graded to $\mathrm{ZrC}, \mathrm{ZrC}$ graded to $\mathrm{LTI}$, doublegraded LTI $\rightarrow \mathrm{ZrC} \rightarrow \mathrm{LTI}$, and $\mathrm{ZrC}$-alloyed isotropic pyrolytic-carbon coats have been made. A single coating run can produce the single- or the doublegraded coat. All of these can be done with no serious problems-the coating process tends to proceed smoothly and coats are laid down as expected from the prerun coating calculations. The $\mathrm{ZrC}$ has been made from the reaction between $\mathrm{ZrCl}_{4}$ and $\mathrm{C}_{2} \mathrm{H}_{6}$, thus utilizing the LTI feed gas throughout (the $\mathrm{C}_{3} \mathrm{H}_{6}$ is used for the doped co-deposit and for the LTI); it has also been made by switching to $\mathrm{CH}_{\text {, for the pure }}$ $\mathrm{ZrC}$. There is no observable difference between coats made using $\mathrm{CH}_{4}$ and $\mathrm{C}_{2} \mathrm{H}_{6}$.

Process parameters for fabrication of $\mathrm{ZrC}_{\mathbf{z}}$ have been identified quantitatively and documented. ${ }^{6.8}$ Experiments designed to identify the critical process parameters for the $\mathrm{ZrC}$-alloyed LTIs have been reported." These latter experiments are very complex and probably could not have been done without the powder feeder. The actual coating-run data have also been documented. ${ }^{10}$

\section{THE GRAPHITE-EXTRUSION PROGRAM}

This part of the effort was also very successful." Extrusion of coated particles into high-density graphite matrices is a demonstrated LASL capability [the Rover and UHTREX (Ultra-HighTemperature Reactor Experiment) reactor fuels were made in this manner.] That this technology could be applied to HTGR and very-hightemperature recctor (VHTR) fuels has been amply demonstrated. The thermal properties of these fuels 
have been as predicted, and the observed irradiation behavior has been exemplary. Our views on the viability and behavior of the high-thermalconductivity graphite matrix fuels for hightôsnperature, gas-cooled reactor applications are set forth in Appendix $B$. The fabrication process has been shown to be amenable to drastic decreases in heat-treatment times and suitable for high-capacity ruel-rod production. Coated-particle volume loadings of $45 \%$ were made for the ORNL HRB-13 experiment without difficulty. Thus far, our experience in making extruded fuels encourages us to think that the upper limit to the extrusion process may be the limit due to random particle packing (i.e., the same limit imposed on the injectionmolding method).

\section{CESTUM DIFFUSION IN ZrC}

To compare the relative effectiveness of $\mathrm{ZrC}$ visa-vis $\mathrm{SiC}$ as a fission-product barrier in fuel structures for high-temperature, gas-cooled reactor applications, a series of cesium infusion experiments on various $\mathrm{ZrC}$ powders and $\mathrm{ZrC}$-coated graphite structures was performed to study the cesium solubility, diffusivity, and permeability of this coating material. 20 The $\mathrm{ZrC}$ powder results vield a cesium solubility in $\mathrm{ZrC}$ of

\section{$\mathrm{S}(\mathrm{ppm} w \mathrm{w})=1.7 \times 10^{-8} \exp -[229 \mathrm{~kJ} / \mathrm{RT}]$}

over the temperature range ( $T$ ) $1485-1896 \mathrm{~K}$ ( $R$ is the gas constant). The diffusion coefficient of cesium in $\mathrm{ZrC}$ is $10^{-18}$ to $10^{-10} \mathrm{~m}^{2} / \mathrm{s}$ over a similar temperat 1 re interval. The activation energy of diffusion is estimated to be $50 \mathrm{~kJ} /$ mole.

The results support the conclusion that $\mathrm{ZrC}$ is comparable to $\mathrm{SiC}$ as a diffusion barrier to cesium.

\section{IRRADIATION RESULTs}

Irradiation tests have been performed on LASL's fuel rods or fuel-rod components. These are summarized:

- Fission-gas release tests were performed on LASL-made, $\mathrm{ZrC}$-coated fissile particles in the General Atomic Company (GAC) TKIGA ractor.
Values of release divided by birth ior these particles were in the $10^{-6}$ to $10^{-7}$ range. A value of $10^{-7}$ is very good.

- HT-28 and HT-29.14 Three material types, extruded graphite, hot-pressed $\mathrm{ZrC}$, and inert particles with $\mathbf{Z}$ rC coats, were irradiated in the ORNL HFIR. All materials performed very well except for one set of particles with double-graded C-ZrC-C coats.

- HRB-12. In this ORNL HFIR experiment, ZrC. and SiC-coated fissile particles are in the same fuel rod. LASL made the $\mathrm{ZrC}$ and outer (o) LTI for half the particles; ORNL made the SiC and o LiTI for the other half. The postirradiation examination is going on in the ORNL hot cells as this report is being written. We are told that, aside from a slight "peppery" appearance, a preliminary examination shows that the $\mathrm{ZrC}$ has been well behaved with respect to radia tion damage and fission-product retention.

- HT-31. Materials tested consisted of three extruded fuel rods that contained TRISO fissile particles (made at ORNL) using $6.36 \%$ enriched ${ }^{2 a s} \mathrm{JC}_{2}$, $\mathrm{ThO}_{2}$ BISO fertile particles, and $\mathrm{ZrC}$-containing inert particles with pure $\mathrm{ZrC}$ coats and $\mathrm{ZrC}$-doped LTI coats. Nominal test conditions were $8 \times 10^{21} \mathrm{n}$ $\mathrm{cm}^{-2}(\mathrm{E}>0.18 \mathrm{MeV})$ at $1525 \mathrm{~K}$. All materials behaved very well. To a first approximation. the graphite matrices and the LASL-made particles showed no effects from the irradiation.

- OF-2. ${ }^{18}$ Three LASL-made substoichiometric ZrC-coated particles with inert kernels and two high-density molded-graphite fuel rods that contained LASL-made ZrC-coated fissile particles were irradiated in the Oak Ridge Research Reactor test OF-2. The severest test conditions were $8.36 \times 10^{21} \mathrm{n}$ $\mathrm{cm}^{-2}(\mathrm{E}>0.18 \mathrm{MeV}$ ) at $1625 \mathrm{~K}$. The graphite matrix showed no effect of the irradiation. There was no interaction between the matrix and any of the particle coats. The loose $\mathrm{ZrC}$-coated particles with inert kernels showed no irradiation effect. The graded ZrC-C coats on the fissile particles were cracked. It is postulated that the cracking is associated with the low LTI deposition rate and is not related to the $\mathrm{ZrC}$.

- HT-32. Three LASIL extruded fuel rods using LASL fertile ZrC-TRISO particles are being tested. No Thermax* was used in the fuel-rod matrices.

*R. T. Vanderbilt. Ce., Inc., New York, NY 10017. 
One of the rods was made using an accelerated 2day total heat-treatment schedule. Irradiaiion star. ted in October 1976, and there are no reported results at the time this report is being written.

- HRB-13. Eight LASL extruded fuel rods are being tested. LASL ZrC-containing fissile TRISO particles with $\mathrm{ZrC}$ coats and $\mathrm{ZrC}$-doped LTIs were employed. All fuel rods were heat-treated using the 2day heat-treatment schedule. The maximum fuelrod heat-treatment temperature was $2375 \mathrm{~K}$. Irradiation started in October 1976, and there are no reported results yet.

\section{DOCUMENTATION OF THE PROJECT}

As the project advanced, significant accomplishments were written up and published as journal articles or as LA reports (TID-4500 UC-77 distribution). When the subject matter was of general scientific interest and also of direct interest to those involved with gas-cooled reactors, it was published both ways. The reference list includes all the 15 reports and articles thati were written on the project. With two appendixes, one on the 76-mm coater and the other on graphite thermal conductivity, this final report completes the documentation of the work that was done.

\section{CONCLUDING REMARKS}

From early 1973 until mid-1977 we worked on the VHTR advanced fuels. This project was initiated by LASL and later funded by the US Atomic Energy Commission-Energy Research and Development Administration (AEC-ERDA), Overall, the results of the laboratory work on the particle fuels, the extrusion work on the fuel rods, and the available results of the irradiation tests far exceeded our expectations. This work was done with the GACHTGR design in mind and the technology developed could be applied today to the HTGR with no modification whatever of the basic core design. Use of the LASL extruded fuel in the HTGR would increase the mean gas exit temperature at least $100 \mathrm{~K}$ with an attendant increase in thermal (and plant) efficiency. This $\Delta T$ is based on a conservative thermal analysis of the HTGR core. ${ }^{2}$ Because the $\mathrm{ZrC}$ - costed fuels are also capable of higher operating temperatures than the fuels now used, still higher gas exit temperatures could be achieved by using these fuels. For use of a prismatic core reactor in a nuclear process heat system, the $\mathrm{ZrC}$-coated particle fuel and the high-density, high-thermalconductivity fuel matrix are essential if the process temperatures necessary for iron-ore reduction and water-splitting are to be reached.

Another desirable aspect of the extrusion technique is economic. The graphite industry finds continuous extrusion methods for dry-cell electrodes more economical than molding the individual electrodes. Many standard-size electrodes made this way are not largely different in size from the HTGR fuel rods. By analogy, a continuous extrusion process for the fuel rods would be more economical than the individual fuel-roi moldings now contemplated for the HTGR.

We have tried, in this report and in the other project documentation, to present a complete description of the fabrication technology, laboratory behavior, high-temperature irradiation behavior, and operating promise of the $\mathrm{ZrC}$-coated particle fuels and the high-density graphite fuel rods.

\section{ACKNOWLEDGMENTS}

This was a complex project and there was considerable interaction with other organizations and people. Significant contributions to the project were made by personnel from the General Atomic Company HTGR Project, the European Dragon Project, KFA of the Federal Republic of Germany, and the ERDA Headquarters staif.

Personnel at the Oak Ridge National Laboratory were esfecially helpful in planning, performing, and doing the postirradiation examination for the irradiation experiments. In particular, the help of $\mathrm{J}$. H. Coobs, F. J. Homan, W. P. Eatherly, R. L. Beatty, E. L. Long, Jr., T. N. Tiegs, and the ORNL hot-cell crew was invaluable to the program; their aid and encouragement is gratefully acknowledged.

LASL personnel who participated actively in this program were R. J. Bard, C. M. Hollabaugh, R. W. White, L. A. Wahman, R. D. Reiswig, J. A. O'Rourke, L. E. Lanham, W. A. Stark, Jr., K. V. Davidson, D. H. Schell, and P. Wagner. The success 
of the program is due in equal part to each of these scientists.

\section{REFERENCES}

1. P. Wagner, "The Dependence of Thermal Conductivity of Binder Residues on Heat Treatment Temperatures," Carbon 14, 71-73 (1976) and "Effects of Heat Treatment Temperature on Binder Thermal Conductivities," Los Aiamos Scientific Laboratory report LA-6181 (February 1976).

2. J. D. Balcomb and P. Wagner, "Extending the Temperature Range of the HTR" in High Temperature Reactor and Process Applications, Joyce S. Davis, Ed., Proc. Br. Nucl. Energy Soc. Int. Conf., London, November 26-28, 1974 (BNES, London, 1975), pp. 25.1-25.5.

3. Charles M. Hollabaugh, Ralph W. White, Lyle A. Wahman, and Paul Wagner, "Method for Producing Graded ZrC-C Coating on Nuclear Fuel Partic'es," US patent applied for; disclosure, November 1974.

4. C. M. Hollabaugh, R. D. Reiswig, P. Wagner, L. A. Wahman, and R. W. White, "A New Method for Coating Micrnspheres with Zirconium Carbide and Zirconjum Carbide-Carbon Graded Coats," J. Nucl. Mater. 57, 325-332 (1975) and Los Alamos Scientific Laboratory report LA-6012 (September 1975).

5. P. Wagner, C. M. Hollabaugh, and R. J. Bard, "ZrC, A Key Ingredient for High Temperature Nuclear Fuels" in Gas-Cooled Reactors with Emphasis on Advanced Systems, Proc. IAEA Symp., Juelich, FRG, October 13-17, 1975 (IAEA, 1976), Vol. I.

6. P. Wagner, R. D. Reiswig, C. M. Hollabaugh, R. W. White, K. V. Davidson, and D. H. Schell, "Irradiation Test HT-31: High-Temperature Irradiation Behavior of LASL-Made Extruded Fuel Rods and LASL-Made Coated Particles," Los Alamos Scientific Laboratory report LA-6785-MS (April 1977).

7. P. Wagner, L. A. Wahman, R. W. White, C. M. Hoilabaugh, and R. D. Reiswig, "Factors Influenc- ing the Chemical Vapor Deposition of ZrC," J. Nucl. Mater. 62, 221-228 (1976).

8. C. M. Hollabaugh, L. A. Wahman, R. D. Reiswig, R. W. White, and P. Wagner, "Chemical Vapor Deposition of ZrC Made by Reactions of $\mathrm{ZrCl}_{4}$ with $\mathrm{CH}_{4}$ and with $\mathrm{C}_{4} \mathrm{H}_{4}$, Nucl. Technol. 35 (1977).

9. C. M. Hollabaugh, R. D. Reiswig, P. Wagner, L. A. Wahman, and R. W. White, "Chemical Vapor Deposition of Zirconium Carbide Alloyed Isotropic Carbon In A Fluidized Bed," Proc. 6th Int. Conf. Chem. Vap. Depositirn, Atlanta, Georgia, October 10-13, 1977 (Electrcchemical Society, 1977), pp. 419-429.

10. C. M. Hollabaugh, P. Wagner, L. A. Wahman, and R. W. White, "Fuel Particle Coating Data, "Los Alamos Scientific Laboratory report LA-6558-MS (January 1977).

11. D. H. Schell, K. V. Davidson, C. M. Hollabaugh, R. D. Reiswig, and P. Wagner, "Improved Matrix For Coated Particle Fuels," paper presented at the 13th Bienn. Conf. Carbon, Irvine, California, July 1977.

12. P. Wagner, "Phonon Scattering in Graphite," Los Alamos Scientific Laboratory report LA-6314 (June 1976).

13. W. A. Stark, Jr., "Cesium Solubility, Diffusion, and Permeation In Zirconium Carbide," accepted for publication in J. Nucl. Mater.

14. R. D. Reiswig, P. Wagner, C. M. Hollabaugh, R. W. White, J. A. O'Rourke, K. V. Davidson, and D. H. Schell, "Behavior of LASL-Made Graphite, ZrC, and $\mathrm{ZrC}$-Containing Coated Particles in Irradiation Tests HT-28 and HT-29," Los Alamos Scientific Laboratory report LA.6211 (May 1976).

15. P. Wagner, R. D. Reiswig, C. M. Hollabaugh, R. W. White, J. A. O'Rourke, K. V. Davidson, and D. H. Schell, "Irradiation Test OF-2: High Temperature Irradiation Behavior of LASL-Made Fuel Rods and LASL-Made Coated Particles," Los Alamos Scientific Laboratory report LA-6988-MS (October 1977). 


\section{APPENDIX A}

\section{6-mm COATER}

As the fuels program progressed, the need for a coater with the capability of satisfying the needs of the extrusion portion became increasingly evident. With this in mind, we designed and built a $76 . \mathrm{mm}$ diam coater. An isometric view of the coater, gas manifold, and $\mathrm{ZrCl}$, powder feeder is shown in Fig. A-1. The coater itself is made of graphite; a single nozzle with a $60^{\circ}$ cone is used for fluidizing the bed. Temperature control is accomplished with a $50-\mathrm{kW}$, $10-\mathrm{kHz}$ induction power supply. Two nozzle inlets are used; $6.4 \mathrm{~mm}$ for carbon coating and $9.5 \mathrm{~mm}$ for $\mathrm{ZrC}$ coating. The maximum coater temperature is about $1825 \mathrm{~K}$. The coater has been completed for

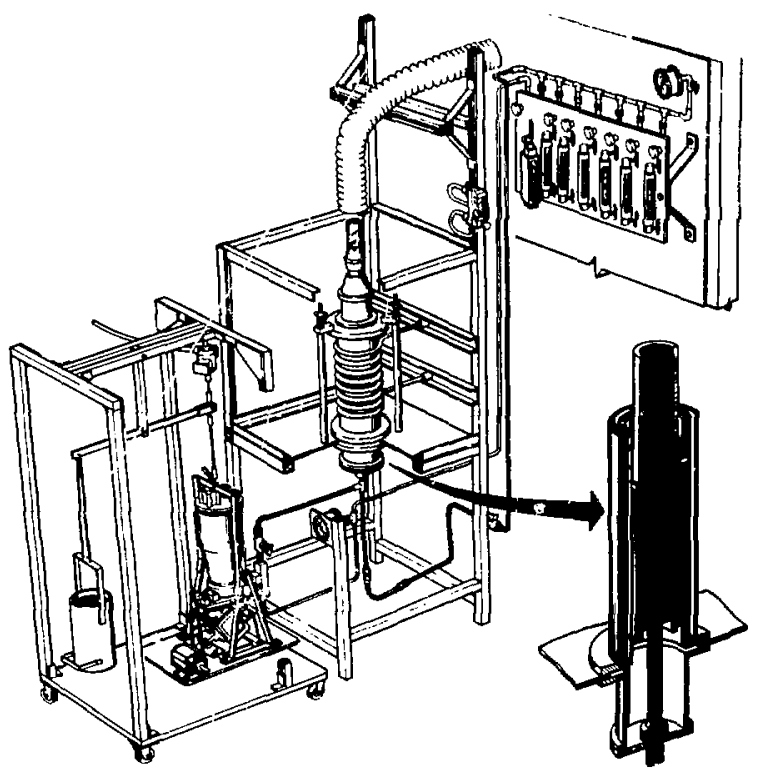

Fig. A-1.

LASL 76-mm coater showing coater, gas manifold, and $\mathrm{ZrCl}$, powder feeder. about 1 yr and has been productive for about 7 months.

To date, the coater has been used for coating both low-density (carbon) and high-density $\left(\mathrm{ThO}_{2}\right)$ kernels. These have been coated successfully in sizes from 175 to $700 \mu \mathrm{m}$ in diameter. These particles have been coated with buffer coats, inner and outer LTIs, $\mathrm{ZrC}$, graded $\mathrm{ZrC}$, and $\mathrm{ZrC}$-C composites. Particles coated in the $76-\mathrm{mm}$ coater and supplied to the extrusion effort have been inert shims of fissile and fertile sizes, shim particles that were used for materials tests in irradiations (i.e., inert particles with $\mathrm{ZrC}$ coats in some form), and $\mathrm{ZrC}$-coated $\mathrm{ThO}_{2}$ particles that will be used in the HT-32 fuel-rod irradiations. Specialized jobs such as coating the particles for the cesium diffusion experiments have also been done in this coater.

Overall, the coater can make seven coating runs in 10 days on the average. This amounts to about a liter of coated particles every 2 weeks. Because a typical extrusion mix is about $200 \mathrm{~cm}^{3}$ and the particles take up $40 \mathrm{vol} \%$, or $80 \mathrm{~cm}^{9}, 2$ week's production can supply enough particles for 12 extrusions. Extrusions in which the particle content is diluted with shims can be made in proportionately larger num. bers. Except for occasional mechanical failures, which require shutdown of the coater, operating experience with the $76-\mathrm{mm}$ coater has been quite satisfactory. Normally, all of the product of a coating run is acceptable, suggesting that the fluidization and agitation in the coater is uniform.

The $\mathrm{ZrC}$ is deposited at $0.003-0.005 \mu \mathrm{m} / \mathrm{s}$ and a typical $\mathrm{ZrC}$-coating experiment will last abou $2 \mathrm{~h}$ it the coating temperature. Satisfactory $\mathrm{ZrC}$ soats aave been made with both $\mathrm{CH}_{4}$ and $\mathrm{C}_{3} \mathrm{H}_{0}$ in the 76 $\mathrm{mm}$ coater. These do not have any obvious structural differences. Other coats (LTI, ZrC-doped LTI, buffer) have also been made effectively in the coater. 


\section{APPENDIX B}

\section{THERMAL CONDUCTIVITY OF EXTRUDED HIGH-DENSITY GRAPHITIZED FUEL RODS}

\section{INTRODUCTION}

The logic of the high-temperature fuels program is based on the desirability of using coated-particle fuels that have been incorporated into highthermal-conductivity $(\lambda)$ graphite matrices in hightemperature gas-cooled reactors (GCRs). As the program has progressed and experimental data have become available, this logic has been continually reexamined. The goal of making a high-temperature fuel that retains a significant $\lambda$ advantage over fuels now in use despite the hostile thermal and radiation environment of an operating GCR has been the focus of this scrutiny. In general, the high-density graphite matrices seem to behave as well or better than had been anticipated at the start of the program. This is a brief discussion of the current thinking and some estimates on the behavior of the graphite matrices being used in the hightemperature fliels program.

At the onset, it was clear that graphite matrices could be made using existing extrusion methods and materials with room-temperature thermal conductivities in the region $50-100 \mathrm{~W} \mathrm{~m}^{-1} \mathrm{~K}^{-1}$ ( $\lambda$ for pitchinjected fuel rods is about $7 \mathrm{~W} \mathrm{~m}^{-1} \mathrm{~K}^{-1}$ at $300 \mathrm{~K}$ ). This, however, is true only if the graphite can be heat-treated to a temperature that will allow the binder phase to graphitize* enough to become a goud thermal conductor.

The mechanism for this improvement of thermal conductivity in graphite may be illustrated by the following example. Consider the thermal conductivity of an artificial graphite consisting of particles of a well-graphitized material that have been coated with a hydrocarbon binder and that has been heated to a temperature of $2075 \mathrm{~K}$. This is a two-phase system in which the binder is the continuous phase and the graphite particles are the discontinuous phase. The binder has a $\lambda$ at $300 \mathrm{~K}$ of $7-10 \mathrm{~W} \mathrm{~m}^{-1}$

*Graphite that has been preheated to $~ 3000 \mathrm{~K}$ allowing the structure to develop and form a highly crybtalline material. Reasonably isotropic graphites made this way have thermal conductivities $>100 \mathrm{~W} \mathrm{~m}^{-1} \mathrm{~K}^{-1}$.
$\mathrm{K}^{-1}$ (Ref. 1) and thus will be the major thermal resiptance in the graphite. Heat treatment at higher temperatures allows the binder to graphitize and $\lambda$ to increase. We ran experiments to quantify this. ${ }^{1}$ In the graphites used, increasing the heat-treatment ten., crutures from 2075 to $2475 \mathrm{~K}$ increased $\lambda$ (300 K) of the polyfurfuryl alcohol (PFA) from about 10 $\mathrm{W} \mathrm{m} \mathrm{m}^{-1} \mathrm{~K}^{-1}$ to $25 \mathrm{~W} \mathrm{~m}^{-1} \mathrm{~K}^{-1}$, which was, in turn, effective in raising $\lambda(300 \mathrm{~K})$ for the graphite from about $65 \mathrm{~W} \mathrm{~m}^{-1} \mathrm{~K}^{-1}$ to about $80 \mathrm{~W} \mathrm{~m}^{-1} \mathrm{~K}^{-1}$ (See Fig. B-1).

Once the decision to use the high-density, highthermal-conductivity graphite as a fuel matrix has been made, the questions to be addressed are:

(a) Can it be made as a coated-particle fuel matrix?

(b) What is the net effect of temperature on $\lambda$ for this matrix compared with that for the pitchinjected fuel rods?

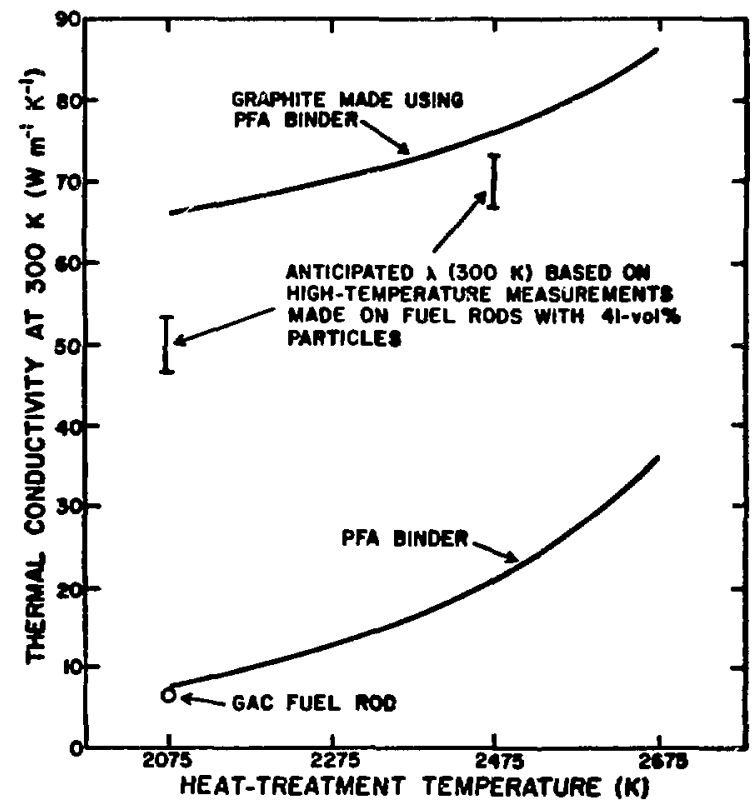

Fig. $B-1$.

Effect of heat-treatment temperature on thermal conductivity of some graphitic materials. 
(c) What is the net effect on $\lambda$ of irraciation on this matrix compared with that for the pitchinjected fuel rods?

(d) When the combined effects are considered, does the graphitized matrix have an operational advantage over the pitch-injected fuel rods?

\section{EXTRUDED FUTL RODS}

The answer to the first question, that of coatedparticle graphite matrix fabrication, has been effectively demonstrated. Although fuel-rod development has been done using $41-\mathrm{vol} \%$ (the mean HTGR core loading) coated particles in the fuel rods, we estimate that, by using methods and materials thus far employed, fuel rods with $50-\mathrm{vol} \%$ coated particles can also be made. The $41-v o l \%$ fuel rods have matrix densities of about $1.65 \mathrm{~g} \mathrm{~cm}^{-3}$. The anticipated $300-\mathrm{K}$ thermal conductivities are about $50 \mathrm{~W} \mathrm{~m} \mathrm{~m}^{-1} \mathrm{~K}^{-1}$ when heat-treated at $2075 \mathrm{~K}$ and about $70 \mathrm{~W} \mathrm{~m}^{-1} \mathrm{~K}^{-1}$ when heat-treated at $2475 \mathrm{~K}$ (see Fig. B-1).

\section{EFFECT OF TEMPERATURE}

To examine the effect of temperature on $\lambda$ for a 41-vol\% particle-loaded fuel rod, $\lambda$ was measured in the region $1475-1875 \mathrm{~K}$. A radial hent-flow method ${ }^{2}$ was used to obtain $\lambda$ in a direction perpendicular to the fuel-rod extrusion axis. This is the heat-flow direction in the prismatic block configuration. The thermal conductivity in this temperature region was about $20 \mathrm{~W} \mathrm{~m}^{-1} \mathrm{~K}^{-1}$ for a fuel rod heat-treated at $2075 \mathrm{~K}$. After heat treatment at $2475 \mathrm{~K}, \lambda$ measured at $1775 \mathrm{~K}$ was about $26 \mathrm{~W} \mathrm{~m}^{-1} \mathrm{~K}^{-1}$. For artificial graphites made using a PFA binder, with a matrix density of $1.65 \mathrm{~W} \mathrm{~m}^{-1} \mathrm{~K}^{-1}$, an effective crystallite beight, $L_{c}$, in the matrix of $\sim 300+A, d_{202}=3.36 \mathrm{~A}, a$ $\mathrm{BAF}$ of 1.3 , and an electrical resistivity of $2000 \mu \Omega$ $\mathrm{cm}$ at $1775 \mathrm{~K}$, the value of $\lambda$ at $300 \mathrm{~K}$ is $2-1 / 2$ to 3 times its value at $1775 \mathrm{~K}$. This corresponds to a $\lambda$ $(300 \mathrm{~K})$ of $50 \mathrm{~W} \mathrm{~m}^{-1} \mathrm{~K}^{-1}$ for a fuel rod heat-treated at $2075 \mathrm{~K}$ and $65-75 \mathrm{~W} \mathrm{~m}^{-1} \mathrm{~K}^{-1}$ for one heat-treated at $2475 \mathrm{~K}$. The pitch-injected-type fuel rod has $\lambda$ $(300 \mathrm{~K})$ in the region $7.10 \mathrm{~W} \mathrm{~m}^{-1} \mathrm{~K}^{-1}$ and a modest decrease with temperature. LASL systems analysis studies on HTGR have used a temperature. independent $\lambda=6.9 \mathrm{~W} \mathrm{~m}^{-1} \mathrm{~K}^{-1}$ for the pitchinjected fuel rods.

It is clear that high-density, well-graphitized fuel rod matrices possess a thermal conductivity advantage of at least a factor of 3-4 over pitch-injected fuel rods at $1775 \mathrm{~K}$. This advantage should be even greater at lower temperatures.

\section{EFFECT OF IRRADIATION}

The effect of irradiation on a high-density graphite matrix of the type discussed is to decrease $\lambda$. Changes in $\lambda(300 \mathrm{~K})$ as a function of fluence for LASL graphites irradiated in HT-29 have been reported $^{s}$ and are shown in Fig. B-2. For the graphite heat-treated at $247 j \mathrm{~K}, \lambda(300 \mathrm{~K})^{4}$ decreased from $80 \mathrm{~W} \mathrm{~m}^{-1} \mathrm{~K}^{-1}$ to about $15 \mathrm{~W} \mathrm{~m}^{-1}$ $\mathrm{K}^{-1}$ after $9.7 \times 10^{21} \mathrm{n} \mathrm{cm}^{-3}$ at $1175 \mathrm{~K}$. A pitchinjected fuel rod would be expected to have $\lambda(300$ $\mathrm{K})$ of about $4 \mathrm{~W} \mathrm{~m}^{-1} \mathrm{~K}^{-1}$ after a similar irradiation. Before end of life (EOL), the value of $\lambda_{\text {extruded }} / \lambda_{\text {pttch }}$ is even more favorable.

*These measurements were made paralle] to the extrusion axis. Perpendicular values are about $75 \%$ of these, before irradiation.

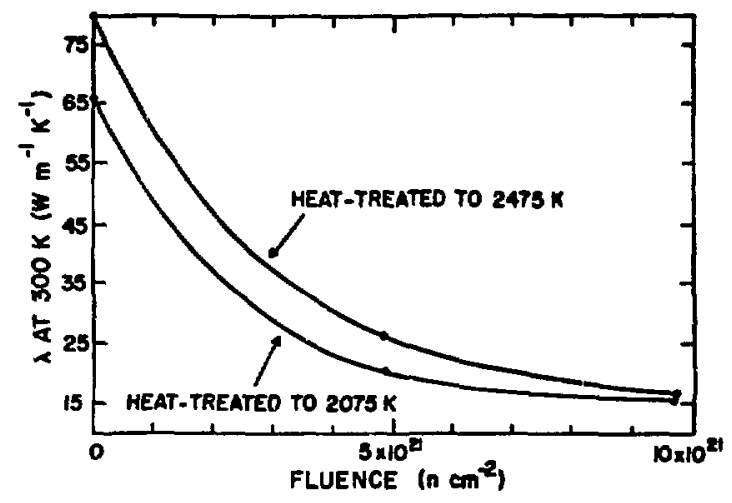

Fig. B-2.

Effect of irradiation on thermal conductivity of two LASL graphites (measurements made parallel to extrusion axis). 


\section{COMBINED EFFECT OF TEMPERATURE AND IRRADIATION}

The total thermal conductivity in graphite is

$\lambda=\lambda_{0}+\lambda_{p}$

where $\lambda_{0}$ is the electronic component and $\lambda_{p}$ is the phonon component of the heat transfer within the graphite. In well-graphitized, reasonably isotropic, polycrystalline, artificial graphites, $\lambda_{0}$, as calculated from the Wiedemann-Franz law, contributes about $2 \%$ of the total thermal conductivity. Although various theorists have estimated $\lambda_{0}$ to be as high as $15 \%$ of $\lambda$, all agree that above room temperature it is the conduction of heat by phonons that is the important mechanism in graphite. The phonon component is given by

$\lambda_{p}=\frac{1}{3} \sum_{j=1}^{n} c_{i} u_{i} \ell_{i}$.

where $c_{1}$ is heat capacity, $u_{1}$ is phonon velocity, and $\ell_{1}$ is the phonon mean free path, all for the ith acoustic mode. The phonon component, and thus $\lambda$, is a strong function of $\ell_{1}$, and changes in $\lambda$ may be considered in terms of changes in phonon mean free path. Effects of temperature on $\lambda$ in graphite are readily interpreted in these terms, because above $350 \mathrm{~K}$ enough vibrational modes are excited that the phonons interact with each other and are scattered, thus decreasing $\ell$. Solid state theory says that for phonon-phonon scattering,

$\lambda \sim \ell \sim 1 / \mathrm{T}$,

and this is indeed the form of the graphite $\lambda$ vs temperature curve from about 400 to $2500 \mathrm{~K}$.

The effects of irradiation on thermal conductivity are analyzed in a similar manner. Graphite has a layered structure, and it is the phonons in the ab plane that are effective in heat transfer. Impurities, interstitials, or displaced atoms $\mathrm{s}^{0.8}$ are all effective in reducing the periodicity of the graphite lattice and acting as scattering centers. The dependence of the mean free path on defects in the lattice is generally taken to be $\ell \sim 1 / \mathrm{c}$

where $\mathrm{c}$ is the concentration term of the defect involved. Thus, effects on the thermal conductivity due to $\mathbf{T}$ or to $\mathrm{c}$ may be similar.

Because both phenomena reduce the phonon mean free path, changes due to temperature and to irradiation are most pronounced in graphites with high degrees of crystalline perfection. Therefore, the extruded, highly crystalline, high-density fuel rods are more affected by temperature and irradiation than are the poorly graphitized fuel rods made by pitch injection. This also explains why irradiation has a larger effect on graphites heat-treated at 2475 $K$ (and thus more fully graphitized) than those heat-treated at $2075 \mathrm{~K}$ (see Fig. B-2).

There is, however, an additional interaction of temperature with irradiation damage to the granhite; temperature anneals some of the damage. That 18 , the higher the irradiation temperature, the more any irradiation damage is annealed and the less irradiation affects $\lambda$. This is brought out very nicely in Price 's article ${ }^{b}$ about irradiation effects on $\lambda$ of graphites irradiated in OG-2."

One other effect must be noted. As thermal and irradiation effects degrade the crystalline perfection of the graphite lattice, further irradiation and ther$\mathrm{mal}$ imperfections have a lessening influence. Thus if the graphite shown in Fig. B-2 had been irradiated at some higher temperature than $1175 \mathrm{~K}$, the $\lambda(300$ $\mathrm{K})$ would have been higher. Curves of $\lambda(300 \mathrm{~K})$ vs fluence in Price's article show that $\lambda(300 \mathrm{~K})>50 \mathrm{~W}$ $\mathrm{m}^{-1} \mathrm{~K}^{-1}$ for all graphites irradiated at $>1275 \mathrm{~K}$ and $<50 \mathrm{~W} \mathrm{~m}^{-1} \mathrm{~K}^{-1}$ for those graphites irradiated at lower temperatures. Based on these considerations, it would be estimated that the $\lambda$ advantage after an irradiation of $9.7 \times 10^{21} \mathrm{n} \mathrm{cm}^{-2}$, of the extruded fuels as compared to the pitch-injected fuels, would be considerably greater than a factor of 4 as the irradiation temperature was increased.

To summarize, irradiation has an adverse effect on $\lambda$; high-temperature operation decreases $\lambda$ but ameliorates the irradiation damage effects. The higher the irradiation temperature, the less the overall effect. 


\section{SUMMARY}

- The fabrication of high-density, wellgraphitized matrices containing $41-\mathrm{vol} \%$ coated particles has been demonstrated.

- At high temperature $(1775 \mathrm{~K})$ these matrices have a factor of 3-4 improvement in $\lambda$ over the pitchinjected fuel rods at the same temperature.

- After irradiation at $1175 \mathrm{~K}$, the value of $\lambda(300$ $\mathrm{K}$ ) of the high-density matrix is estimated to have a thermal conductivity 3-4 times that of the pitchinjected fuel rods at EOL.

- The combined effects of high-temperature operation aiid irradiation on the high-density graphite matrix should result in a rod with a distinct heat-transfer advantage ( $>4$ times) over the pitchinjected system. This should be true throughout the reactor operation lifetime with the minimum advantage occurring at EOL.

While the evidence has just started to come in on the performance of the high-density graphite fuel rods, all indications are that it is a system with demonstrable thermal performance advantages over the pitch-injected fuel rods.

\section{REFERENCES}

1. P. Wagner, "Effect of Heat Treatment Temperature on Binder Thermal Conductivities," Los Alamos Scientific Laboratory report LA-6181 (February 1976).

2. P. Wagner and L. B. Dauelsberg, "Thermal Conductivity of ZTA Graphite," Carbon 5, 271-279 (1967).
3. P. Wagner and L. B. Dauelsberg, "Some Thermal Properties of a Polyfurfuryl Alcohol Bonded Graphite," Carbon 7, 273-278 (1969).

4. G. E. Cort, J. C. Vigil, and R. J. Jiacoletti, "Predicted Nuclear Heating and Temperatures in Gas-Cooled Nuclear Reactors for Process Heat Applications," Los Alamos Scientific Laboratory report LA-6113-MS (October 1975).

5. R. D. Keiswig, P. Wagner, C. M. Hollabaugh, R. W. White, J. A. O'Roure, K. V. Davidson, and D. H. Schell, "Behavior of LASL-Made Graphite, ZrC, and $\mathrm{ZrC}$-Containing Coated Particles in Irradiation Tests HT-28 and HT-29," Los Alamos Scientific Laboratory report LA-6211 (May 1976).

6. P. Wagner and J. M. Dickinson, "Ambient and High Temperature Experiments on Boron-Doped Polycrystalline Graphites," Carbon 8, 313-320 (1970).

7. B. T. Kelly, "The Thermal Conductivity of Graphite," Chem. Phys. Carbon 5, 119-215 (1969).

8. R. J. Price, "Thermal Conductivity of NeutronIrradiated Reactor Graphites," Carbon 13, 201-204 (1975).

9. R. J. Price and L. A. Beavan, "Final Report on Graphite Irradiation Test OG-2," General Atomic Company report GA-A13556 (1975). 